\title{
Education and Research: an Inevitable Requirement for Heritage Preservation in Cultural Memory Institutions
}

JOZEF HANUS, ING. PHD.

Faculty of Chemical and Food Technology, Slovak University of Technology, Radlinského 9, 81237 Bratislava, Slovak Republic

e-mail: jozef.hanus@stuba.sk

\section{Katarína VIZÁROVÁ, Prof. ING. PH.D.}

Faculty of Chemical and Food Technology, Slovak University of Technology, Radlinského 9, 81237 Bratislava, Slovak Republic

e-mail: katarina.vizarova@stuba.sk

Radko TIŇO, Prof. ING. PH.D.

Faculty of Chemical and Food Technology, Slovak University of Technology, Radlinského 9, 81237 Bratislava, Slovak Republic

e-mail: radovan.tino@stuba.sk

\section{Milena ReHÁKOVÁ, Prof. ING. Ph.D.}

Faculty of Chemical and Food Technology, Slovak University of Technology, Radlinského 9, 81237 Bratislava, Slovak Republic

e-mail:milena.rehakova@stuba.sk

\section{Nina LALÍKOVÁ, Mgr. ART.}

Historical Museum of the Slovak National Museum, Podunajské Biskupice, P.O.BOX 13, 81006 Bratislava, Slovak Republic

e-mail: nina.lalikova@snm.sk

\section{EMIILIA HANUSOVÁ, ING.}

University Library Bratislava, Michalská 1, 81417 Bratislava, Slovak Republic

e-mail: emilia.hanusova@ulib.sk

Education and Research: an Inevitable Requirement for Heritage Preservation in Cultural Memory Institutions

$$
\text { ABSTRACT }
$$

If we want to talk about training of archivists in the $21^{\text {st }}$ century we must bear in mind that preservation of documents in their original form has to be one of the most important tasks of archivists - not only in the $21^{\text {st }}$ century but every time. Generally, one of the principal tasks of archives, libraries, museums and other memory institutions is preservation of objects and materials of cultural heritage in their original form. It represents an enormous interdisciplinary complex problem. Participation of experts from different fields of science and technology, practical end-users, conservators and restorers supported by adequate financial background is inevitable in solution of partial problems in this field. The paper informs about the research project "Conservation and stabilisation of cultural heritage objects from natural organic compounds by low temperature plasma" and its aims at the Faculty of Chemical and Food Technology, Slovak University of Technology in Bratislava.

Key words: cultural heritage materials and objects, degradation, conservation, plasma treatment, cleaning, disinfection 
Jozef HANUS - Katarína VIZÁROVÁ - Radko TIŇO - Milena REHÁKOVÁ - Nina LALÍKOVÁ - Emília HANUSOVÁ: Education and Research: an Inevitable Requirement for..., 155-160

Formazione e ricerca: un requisito ineludibile per la conservazione del patrimonio nelle istituzioni di memoria culturale

\section{SINTESI}

Se vogliamo parlare di formazione degli archivisti nel XXI secolo, dobbiamo tener presente che la conservazione dei documenti nella loro forma originale deve essere uno dei compiti più importanti degli archivisti - non solo nel XXI secolo ma sempre. Generalmente, uno dei compiti principali di archivi, biblioteche, musei ed altre istituzioni di memoria è la conservazione degli oggetti e dei materiali del patrimonio culturale nella loro forma originale. Ciò rappresenta un enorme e complesso problema interdisciplinare. La compartecipazione di esperti di diversi settori della scienza e della tecnologia, degli utenti finali, dei conservatori e dei restauratori supportati da un adeguato background finanziario è inevitabile nella soluzione dei problemi in questo campo. L'articolo fornisce informazioni riguardo al progetto di ricerca "Conservazione e stabilizzazione degli oggetti del patrimonio culturale da composti organici naturali mediante plasma a bassa temperatura” e le sue finalità alla Facoltà di Tecnologia chimica e alimentare dell'Università Slovacca di Tecnologia di Bratislava.

Parole chiave: materiali ed oggetti del patrimonio culturale, degrado, trattamento al plasma, pulitura, disinfestazione

Izobraževanje in raziskovanje: neizogibna zahteva za ohranjanje dediščine v institucijah kulturnega spomina

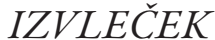

Če želimo govoriti o usposabljanju arhivov v 21. stoletju, moramo upoštevati, da mora biti ohranitev dokumentov v njihovi prvotni obliki ena najpomembnejših nalog arhivov - ne le v 21. stoletju, ampak vedno. Na splošno je ena glavnih nalog arhivov, knjižnic, muzejev in drugih spomeniških institucij ohranjanje predmetov in kulturne dediščine v njihovi prvotni obliki. To pa predstavlja ogromno, zapleteno interdisciplinarno težavo. Sodelovanje strokovnjakov z različnih področij znanosti in tehnologije, praktičnih končnih uporabnikov, konzervatorjev in restavratorjev, ki imajo na voljo ustrzena finančna sredstva, je neizogibno pri reševanju delnih težav na tem področju. Prispevek poroča o raziskovalnem projektu na Fakulteti za kemijsko in prehrambeno tehnologijo Slovaške tehnološke univerze v Bratislavi z naslovom „Ohranjanje in stabilizacija objektov kulturne dediščine iz naravnih organskih spojin z nizko temperaturno plazmo" in njegovih ciljih.

Ključne besede: materiali in predmeti kulturne dediščine, degradacija, konzervacija, plazemska obdelava, čiščenje, dezinfekcija

Vzdelávanie a výskum: nevyhnutná požiadavka pre ochranu dedičstva v kultúrnych pamätových inštitúciách

\section{ABSTRAKT}

Ak chceme hovorit o vzdelávaní archivárov v 21. storočí musíme mat na pamäti, že ochrana archívnych dokumentov v ich originálnej forme je jednou z najdôležitejších úloh archivárov - nielen v 21. storočí, ale v každom čase. Vo všeobecnosti - jednou z hlavných úloh archívov, knižníc, múzeí a ostatných pamätových inštitúcií je ochrana objektov a materiálov kultúrneho dedičstva $v$ ich originálnej podobe. To predstavuje enormnú interdisciplinárnu komplexnú problematiku. Participácia odborníkov z rôznych oblasti vedy a techniky, koncových užívatel'ov v príslušných inštitúciách, konzervátorov a reštaurátorov podporovaná adekvátnymi finančnými prostriedkami je nevyhnutná pri riešení parciálnych problémov v tejto oblasti. Príspevok informuje o výskumnom projekte „Konzervovanie a stabilizácia objektov kultúrneho dedičstva z prírodných organických materiálov nízkoteplotnou plazmou" a jeho ciel'och, ktorý sa realizuje na Fakulte chemickej a potravinárskej technológie Slovenskej technickej univerzity v Bratislave.

\section{Introduction}

If we want talk about the training of archivists in the $21^{\text {st }}$ century - which is one of the topics of the International Archival Day 2017 - we must bear in mind that the preservation of archives and documents in their original form has to be one of the most important tasks of archivists - not only in the $21^{\text {st }}$ century but every time. This is the reason why at the Department of Archiving and Auxiliary Sciences in History of the Comenius University in Bratislava in the master study program of archivists is included also the subject Preservation of archives. The detail information on this topic was published also in ATLANTI 2005 (Hanus et al., 2005). The course provides general information on main degradation factors and preservation of archives. 
In general, preservation of archival documents, library materials and other objects and materials of cultural heritage in their original forms is one of the principal tasks of archives, libraries, museums, galleries and other cultural memory institutions all over the world. As preservation of cultural heritage represents an enormous interdisciplinary complex problem participation of experts from different fields of science and technology, practical end-users, conservators and restorers supported by adequate financial background is an inevitable in solution of partial problems in this field.

In order to be able to solve preservation problems effectively and successfully a specialised study and education in this field - which is called conservation science - is necessary.

Conservation science, with respect to cultural heritage, is the interdisciplinary study of conservation of art, architecture, and other cultural works through the use of scientific inquiry. General areas of research include the technology and structure of artistic and historic works and the materials and media from which they are made. Conservation scientists use scientific methods and principles to support work in the fields of art conservation and architectural conservation, and care of cultural objects in museums and other collections. Cultural conservation science work includes identifying the materials that make up a structure or piece of art including their chemical makeup, identifying and cataloguing changes that cause deterioration and developing methods to mitigate deterioration of cultural heritage (AIC, 2003).

The cultural heritage of the Slovak Republic is an indispensable asset of the State and its citizens, is a testament to the evolution of society, philosophy, religion, science, technology, art, the document of educational and cultural level of the Slovak nation, other peoples, national minorities, ethnic groups and individuals who live or have lived in the territory of Slovakia in the past. For the conservation and maintenance of these values it is necessary to educate and train professionals commanding and controlling both - the principles of conservation and restoration of materials, objects and monuments as well as current and historical materials and technologies for their protection, conservation and stabilization (Bakos et al., 2008).

On the basis of long term cooperation of the Faculty of Chemical and Food Industry in Bratislava with the main cultural memory institution in Slovak Republic, especially the Slovak National Archives, the Slovak National Library, the Slovak National Museum, the Slovak National Gallery, University Library and others, the new study programme "HERITAGE MATERIALS CONSERVATION" within the framework of the study field "Chemical Technology or Engineering Chemistry" at the Faculty of Chemical and Food Technology, Slovak University of Technology in Bratislava has been accredited in 2008. It was presented in details in ATLANTI 2014 (Hanus et al., 2014). The program represents a new conception of education in conservation science on university level in the Slovak Republic (Katušcák et al., 2008, Bakoš et al., 2008, Vizárová \& Reháková, 2013).

Besides the education, basic and applied research within the framework of different projects represents an important and integral part of activities at the Faculty.

This paper provides brief information on the project of applied research "Conservation and stabilisation of cultural heritage objects from natural organic compounds by low temperature plasma" supported by the Slovak Research and Development Agency (01.07.2016 - 31.12.2019). The proposed project is aimed at developing plasma-chemical protection of materials and objects of cultural heritage in order to increase the productivity and improve the quality of conservation intervention.

\section{The main problems in heritage preservation}

The rate of Slovak heritage degradation is much higher than the rate (capacity) of its preservation. Cultural heritage objects exhibit a great variability of material basis (wood, paper, leather, metals, glass, ceramics and other inorganic materials and plastic materials), heterogeneity (works of art are composed from layers differing in composition, books, textile-based objects, historical furniture contains various kinds of materials) and are differing in shape (spacious 3D-objects, 2D-objects - paintings, graphical works, photography, small 3D- objects - statues, museum artefacts, archival and text analogue documents - books etc.).

An important group of cultural heritage objects from the material point of view is represented by the carriers made from the different organic materials (wood, paper, textile, leather, waxes and their modifications), very often consisting of combination of natural polymeric materials. 
Objects of cultural heritage are subject to change due to aging degradation and are often contaminated. They may include mechanical, biological and even chemical pollutants. Specifically, the dust, insects, moulds, fungus and also chemical substances introduced into the production of the material, or impurities such as oxidation products resulting from the reaction with oxygen, ozone, oxides of sulphur and nitrogen, or degradation products of the materials and objects themselves (acid, low molecular weight aldehydes and decomposition of various materials depending on the type of base matrix) are the examples of these contamination. These factors greatly contribute to reducing the life span of the material and thus of the whole object. Important factor is the temperature and humidity of environment in which objects are stored and displayed or high and frequent fluctuation of those parameters. Due to these factors, the material loses its strength and optical characteristics. These phenomena are due to degradation processes, causing degradation of the basic components of a change in the structure of the material. Knowing the connection between changing the structure of the basic components and loss of performance objects are relevant to the application of materials and procedures to stabilize the system (Vizárová, 2012).

The processes and equipments for cleaning, sterilization and/or stabilization up-to-now used in Slovakia and abroad are mostly mono-functional. Another disadvantage lies in application of chemical, frequently toxic and aggressive solvents and substances. To eradicate biological contamination, ethylene oxide (Kowalik, 1980, 1984, Postlethwhite, 1991), phenol derivatives (Valentin, 1986), quarternary ammonium mixtures (Strzeczyk, 1986) or another substances have been applied. Due to the fact that the objects in question contain various materials (dyes, thermoplastic glues, plastics, leather, wax etc.) which are heat-sensitive, classical sterilization procedures carried out at temperatures exceeding $35^{\circ} \mathrm{C}$ cannot be applied in every case.

\section{Proposed plasma treatment procedures}

The advantage of using the proposed procedures for increasing the stability of objects and materials as well as for their disinfection and sterilization is the fact that they can operate at low/ambient temperatures. Another positive effect is the elimination of chemicals used or possibility of application of environmentally friendly systems for achieving the desired effect. It also accomplishes a number of technological operations in one device and one-step application process of disinfection, sterilization and stabilization of objects. This allows the use of plasma-chemical processes in the preservation and conservation on a massive scale. The advantage of the introduction of plasma technology may lie in increasing of labour productivity of individual technological conservation operations like cleaning, stabilization i.e. extending the lifespan of objects, disinfection and sterilization. Plasma-chemical surface treatments of solid materials have been proved in many industries (Rahel et al., 2011, Pavlinak et al., 2012, Rahel et al., 2012). Many research groups pay attention to their use in the protection of materials and objects of cultural heritage in recent years on research level. The highest attention has been devoted to the application of low-pressure plasma at the preservation of metallic objects of cultural heritage. It concerns mainly plasma-chemical removal of stain from iron objects by radiofrequency sparks of hydrogen low-pressure plasma. In spite of the fact that this technique has been utilized at restoration of metallic archeological artefacts, the use of plasma was just of intuitive nature (Lieberman \& Lichtenberg, 1994).

The oxygen-argon plasma can also be used for effective decontamination of objects composed from organic components including photographs (Daniels, 1981, Ioanid et al., 2010) or to remove adhered deposits from the surface of paintings (Rutledge et al., 2000).

Paper is an important carrier of information associated with cultural heritage. Plasma seems to be a promising technology for this field of conservation, too. By means of modification using plasma it is possible to eradicate microbial contaminants in one step along with a simultaneous increase of paper strength (Vohrer et al., 2001). At modifications by plasma (in both oxidation and reduction atmospheres) of naturally wood-containing aged paper it is possible to reach a total increase in paper stability by approximately $20 \%$. A bactericidal effect on microbial decontamination treatment by using of plasma in $\mathrm{O}_{2} / \mathrm{H}_{2}$ atmosphere has been proved (Laguardia et al., 2005). More pronounced stabilization and paper strength increase has been obtained by applying of chitosan to the surface of plasma-activated paper using barrier discharge plasma (Mikula et al., 2009).

Recently, possibilities to deposit polymerised monomers by plasma aimed at paper strengthening and protecting (Totolin \& Neamtu, 2011, Tóth et al., 2007) as well as protecting of metallic parts of cultural heritage objects have been investigated (Totolin et al., 2009). 
Jozef HANUS - Katarína VIZÁROVÁ - Radko TIŇO - Milena REHÁKOVÁ - Nina LALÍKOVÁ - Emília HANUSOVÁ: Education and Research: an Inevitable Requirement for..., 155-160

\section{References}

AIC (2003). The American Institute for Conservation of Historic and Artistic Works: Defining the Conservator: Essential Competencies

Bakoš, D., Katuščák, S., Hudec, I., Čeppan, M., Reháková, M. (2008). Nový študijný program STU: Ochrana materiálov a objektov dedičstva. I. Etapa rozvoja VŠ európskeho vzdelávania Conservation Science na Slovensku. Knižnica, roč. 9, č. 6-7, pp. 14-15

Hanus, J., Hanusová, E., Katuščák, S., Bukovský, V. (2005). The contribution of university education to preservation of archives and library materials. ATLANTI Vol. 15, 1-2 (2005) International Institute for Archival Science of Trieste and Maribor, University of Maribor, State Archive of Trieste, Trieste 2005, CD ROM

Hanus, J., Vizárová, K., Reháková, M., Hanusová, E. (2014). Training and Education: the Key Role in Heritage Preservation of Archives, Libraries and Other Cultural Institutions. ATLANTI Vol. 24 (2014) N. 2, International Institute for Archival Science of Trieste and Maribor, University of Maribor, State Archive of Trieste, Trieste 2014, pp. 165-174, ISSN 1318-0134

Katuščák, S., Katuščák, D., Bakoš, D., Šíma, J., Urlandová, A. (2008). Koncepcia rozvoja konzervačnej vedy, vzdelávania, technológie a priemyslu na Slovensku. Knižnica, roč. 9, č. 6-7, pp. 4-9

Kowalik, R. (1980, 1984). Microbiodeterioration of library materials. Restaurator 4, 1980 and 6, 1984

Laguardia, L., et al. (2005). Investigation of the effect of plasma treatments on biodeteriorated ancient paper. Applied Surface Science 252, pp. 1159-1166

Lieberman M, Lichtenberg A. (1994). Principles of plasma discharges and materials processing (John Wiley \& Sons, New York)

Mikula, M. et al. (2009). Stabilization of paper by nitrogen plasma assisted application of chitosan at atmospheric pressure. Acta Chimica Slovacca 2 (1), pp. 62-69

Pavlinak, D., Alberti, M., Rahel, J. (2012). Plasma-chemical treatment of cellulose materials. In Book of Abstract IDMS 2012 ReAdMat. Pardubice (Czech Republic): University of Pardubice, 2012. ISBN 978-80-7395-524-3, pp. $45-45$

Postlethwaite, A. W. (1991). Achieving integrated pest eradication with heightened sensitivities to collections safety and human toxicity. International seminar on research in preservation and conservation. School of LS Columbia University, IFLA, ICA, Arden House N.Y.

Rahel, J. et al. (2012). DBD Plasma Assisted Silver Functionalization of Surgical Meshes. In: Plasma for Bio-Decontamination, Medicine and Food Security (NATO Science for Peace and Security Series A: Chemistry and Biology). Vyd. 1. Dordrecht, The Netherlands: Springer Series A: Chemistry and Biology, ISBN 978-94-007-2851-6, pp. 417-429

Rahel, J., Stahel, P., Odraskova, M. (2011). Wood surface modification by dielectric barrier dischrages at atmospheric pressure. Chemické Listy, Praha, Ceská společnost chemická. ISSN 0009-2770, 105(CHLSAC 105), p. 125 $-128$

Rutledge S.K., et al. (2000). Atomic oxygen treatment as a method of covering smoke-damaged paintings, Journal of the American Institute for Conservation 39, pp. 65-74

Strzeczyk, A.B., et al. (1986). The effect of disinfection with quaternary salt solution on paper. Restaurator, Vol.7, pp. 3-13

Tóth A., Černáková L., Černák M., Kunovská K. (2007). Surface analysis of groundwood paper treated by diffuse coplanar surface barrier discharge type atmospheric plasma in air and in nitrogen, Holzforschung 61, pp. 528-531

Totolin M.I., Neamtu I. (2011). Positive findings for plasma pollymer (meth) acrylate thin films in heritage protective applications. Journal of Cultural Heritage (available on-line)

Valentin, N. (1986). Biodeterioration of library materials. Disinfection methods and new alternatives. The Paper Conservator, Vol. 10, pp. 40-45

Vizárová, K., et al. (2012). Relationship between the decrease of degree of polymerisation of cellulose and the loss of groundwood pulp paper mechanical properties during accelerated ageing. Chem Papers 66, pp. 1124-1129

Vizárová, K., Reháková, M. (2013). Postavenie a úloha konzervačného vedca v súčasnosti na Slovensku. Interdisciplinarita vo vedeckom výskume pri rozvoji ochrany kultúrneho dedičstva: Zborník príspevkov konferencie CSTI 2013 Conservation Science, Technology and Industry. Bratislava. ISBN 978-80-227-3991-7, pp. 23-29

Vohrer U., Trick I., Bernhardt J., Oehr C., Brunner H. (2001). Plasma treatment - an increasing technology for paper restoration? Surface and Coatings Technology 142-144, pp. 1069-1073 


\section{SUMMARY}

Preservation of documents in their original form has to be one of the most important tasks of archivists - not only in the $21^{\text {st }}$ century but in every time. Generally, one of the principal tasks of archives, libraries, museums and other memory institutions is preservation of objects and materials of cultural heritage in their original form. It represents an enormous interdisciplinary complex problem. Participation of experts from different fields of science and technology, practical end-users, conservators and restorers supported by adequate financial background is inevitable in solution of partial problems in this field. The paper informs about the research project "Conservation and stabilisation of cultural heritage objects from natural organic compounds by low temperature plasma" and its aims at the Faculty of Chemical and Food Technology, Slovak University of Technology in Bratislava. The proposed project is aimed at developing plasma-chemical protection of materials and objects of cultural heritage in order to increase the productivity and improve the quality of conservation intervention. The treatment of solid surfaces with atmospheric plasma discharge is a new modern method that has great potential to solve many problems to which restorers and conservators are facing daily. Moreover, the proposed use of the plasma processing at atmospheric pressure compared to a low pressure (vacuum) plasma systems has the great advantage that it is an energy$\&$ machine-undemanding method enabling in a short time (in order of seconds) effectively decontaminate, clean and preserve objects of historical and artistic value in one step. This eliminates the need for multiple handling of degraded, fragile objects, which significantly helps to eliminate the risk of their further potential damage. The proposed procedures are in line with the latest scientific knowledge from accessible literature. They are also part of the research and practice and have been tested in several scientific research projects.

\section{Acknowledgement}

This work was supported by the Slovak Research and Development Agency under the contract no. APVV-15-0460.

Typology: 1.04 Professional Article

Submitting date: 13.04 .2017

Acceptance date: 05.05 .2017 